\title{
Thymoquinone reduces ischemia and reperfusion-induced intestinal injury in rats, through anti-oxidative and anti-inflammatory effects
}

\author{
Ali $\operatorname{Parlar}^{1}\left(\right.$ ID), Seyfullah Oktay $\operatorname{Arslan}^{2}($ ID) \\ ${ }^{1}$ Department of Medical Pharmacology, Adiyaman University School of Medicine, Adiyaman, Turkey \\ ${ }^{2}$ Department of Medical Pharmacology, Ankara Yildirim Beyazit University School of Medicine, Ankara, Turkey
}

\begin{abstract}
Objective: The aim of the present study was to investigate the effect of thymoquinone on ischemia/reperfusion (I/R) injury at $150 \mathrm{~min}$ or/and $24 \mathrm{~h}$ of reperfusion in male Wistar Rats.

Material and Methods: The therapeutic value of thymoquinone on cellular damage caused by reactive oxygene species or inflammatory processes during intestinal ischemia/reperfusion was investigated using pharmacological function studies on smooth muscle contractile responses of acetylcholine (Ach) and $\mathrm{KCl}$, along with myeloperoxidase activity, malondialdehyhde, glutathione and cytokine levels such as tumor necrosis factor (TNF)- $\alpha$ and interleukin (IL)-1 $\beta$ in serum and ileum tissue of rats. Thymoquinone was administered at a dose of $50 \mathrm{mg} / \mathrm{kg}$ orally for three times: $30 \mathrm{~min}, 24 \mathrm{~h}$ and 48 $\mathrm{h}$ prior to the surgical procedure. Soon after reperfusion timing $(150 \mathrm{~min}$ or $24 \mathrm{~h}$ ), the contractility traces to $\mathrm{KCl}$ and acetylcholine of the ileum smooth muscle were recorded through isolated organ bath.

Results: Pretreatment with thymoquinone reversed the disrupted contractility of the ileum smooth muscle at the $24 \mathrm{~h}$ reperfusion. Increased malondialdehyde and depleted glutathione levels and high myeloperoxidase activity determined in the ileum I/R tissue returned to reasonable amounts by pretreatment of Thymoquinone, which attenuated malondialdehyde quantity, restored glutathione level and inhibited myeloperoxidase activity. In addition, both serum and tissue TNF- $\alpha$ and IL-1 $\beta$ activities were modulated by thymoquinone at $24 \mathrm{~h}$ of intestinal I/R.
\end{abstract}

Conclusion: The results indicate that thymoquinone may have therapeutic value due to its immunomodulating, radical scavenging and/or antioxidant effects in intestinal I/R injury including oxidant damage mechanisms.

Keywords: Thymoquinone, intestinal ischemia and reperfusion, ileum smooth muscle contractility, cytokines, oxidative injury

* The research was discussed at the fifth International Congress of Turkish Society of Pharmacology, 2013, Antalya, Turkey.

Cite this article as: Parlar A, Arslan SO. Thymoquinone reduces ischemia and reperfusion-induced intestinal injury in rats, through anti-oxidative and anti-inflammatory effects. Turk J Surg 2020; 36 (1): 96-104.

\section{Corresponding Author} Seyfullah Oktay Arslan

E-mail: soarslan@gmail.com

Received: 13.07.2019

Accepted: 30.12 .2019

Available Online Date: 18.03 .2020

( Copyright 2020 by Turkish Surgical Society Available online at www.turkjsurg.com

DOI: $10.5578 /$ turkjsurg.4583

\section{INTRODUCTION}

Ischemia due to insufficient blood supply to tissues results in cellular function failure; however, reperfusion exacerbates the ischemic damage more. Actually, the intestinal tissue is quite sensitive to ischemia/reperfusion (I/R) through mesenteric artery. Cellular damages during surgical procedures or pathological conditions including bowel transplantation, acute mesenteric ischemia, abdominal aortic aneurysm, and shock are remarked as the main causes of intestinal I/R injury. Increased protein extravasations, disruption of mucosal barrier, decreased contractile activity, and impairment of gut motility are clearly observed with intestinal I/R (1). The activation of inflammatory cells such as polymorphonuclear leukocytes leads to fast exagreation of the onset of inflammatory reaction. Previous studies have shown that in the pathologenesis of $I / R$, there is an increase in the amounts of reactive oxygen and nitrogen species, cytokines, endotoxins, and neutrophils (2-4). Several studies have also demonstrated that neutrophils, adhesive molecules and endothelial cells are responsible for serious and deleterious cellular inflammatory dysfunction caused by intestinal I/R injury $(3,4)$. It is well known that the produced reactive oxygen or nitrogen species and oxidative damage are the main responsibles of cell death and organ dysfunction in intestinal I/R $(3,5)$.

Thymoquinone (TQ; 2-isopropyl-5-methyl-1,4-benzoquinone) is a therapeutically active chemical structure of the essential and fixed oil obtained from Nigella sativa 
seeds. Recently, data have addressed on its in vivo and in vitro pharmacotherapeutic effects (6). Its antioxidant, anti-inflammatory or immunmodulatory actions have been revealed in several disease models (7-11), as well as in gastric ulcer caused by I/R (9). Moreover, TQ has been shown to inhibit the accumulation of inflammatory cells in bronchial alveolar fluid (BALF) and lung tissue (12). In a study of Tas et al., TQ has been found to cause decreased levels of malondialdehyde (MDA) in ischemia-reperfusion injury while increasing the level of glutathione (GSH) (13). A recent study reveals that $\mathrm{TQ}$ reverses cytokine increases such as tumor necrosis factor (TNF)-a and interleukin (IL)s caused by I/R in both serum and intestinal tissue (13).

For all reasons, it is to prove the hypothesis that the antioxidant and antiinflammatory role of TQ in I/R injury will reduce injury of intestinal ischemia reperfusion. Therefore, this research was planned to reveal the effect of TQ on intestinal I/R.

\section{MATERIAL and METHODS}

\section{Animals}

This study was conducted with forty-eight male Wistar-albino rats weighing 200-250 g in Experimental Research Section of Duzce University. The approval of the animal ethical committee of Duzce University was taken with the number: 2011/009.

\section{Thymoquinone Treatment}

All chemicals used in the study was obtained from Sigma (USA) and was prepared with $1 \%$ Tween 80 to be administered orally. TQ $(50 \mathrm{mg} / \mathrm{kg}$ of body weight per day) or gavage canula $(1 \mathrm{~mL})$ was given orally once a day for 3 days before surgery and 30 min before surgical procedures $(n=8)$. The dose of TQ was administered as done by El-Abhar et al. in their study (14).

\section{Experimental Protocols of Induction of Ischemia/Reperfusion in Intestinal Tissue}

Intestinal I/R was performed as described previously (3). Briefly, under sodium thiopental anaesthetize midline laparotomy was performed, the small intestine was gently naked with humid sterile gauze to block dehydration. After I/R was performed through the occlusion of superior mesenteric artery with a 30-minute schedule using microvascular clamp, ileum was perfused by $150 \mathrm{~min}$. Loss of pulsation and coloration in the bowel was observed in the ischemia period. To let blood flow to the intestines, the clamp was opened gently at the end of 30 minutes. In the experimental protocol, groups were divided as follows:

I. Sham group ( $n=16)$ : The rats underwent laparotomy, without ischemia/reperfusion, remained open until the ischemia/reperfusion period or after 30 minutes of follow-up, the abdominal wall was sutured.

II. I/R-vehicle group without any treated ( $n=16)$ : First, the superior mesenteric artery was occluded with clamp for 30 min and then ischemia was started. Immediately 150 minutes or 24 $\mathrm{h}$ reperfusion was performed and this procedure was also done for the I/R-vehicle after vehicle was given.

III. I/R and TQ-treated group ( $n=16)$ : Animals subjected to ischemia/reperfusion were preadministered with TQ as described above.

Animals were divided into 2 series for 150 min and $24 \mathrm{~h}$ reperfusion studies $(n=8)$. Bioochemical analyses were only measured at $24 \mathrm{~h}$.

\section{Preparation of the Terminal Ileum and Contractile Studies in Intestinal Tissue}

The aim of this process was to evaluate the contractile activity of the ileal longitudinal muscle in isolated ileal segments in organ bath (Commant lletisim Co, Ankara, Turkey). A 15-mm length terminal ileum tissue fragment was cleaned and immediately suspended in an isolated organ bath with a Krebs solution involving $\mathrm{KCl} 4.7, \mathrm{NaHCO}_{3} 24.88, \mathrm{MgSO}_{4} 1.16, \mathrm{KH}_{2} \mathrm{PO}_{4} 1.18, \mathrm{CaCl}_{2} 2.52, \mathrm{NaCl}$ 118 , and glucose 11.1 in $\mathrm{mM}$. Longitudinal segments of the ileum smooth muscle were calibrated during $60 \mathrm{~min}$ at $2 \mathrm{~g}$ force in organ bath filled with Krebs solution regularly fed with a gas mixture of $5 \% \mathrm{CO}_{2}$ and $95 \% \mathrm{O}_{2}$ at $37^{\circ} \mathrm{C}$. Following the $2 \mathrm{~g}$ tension equilibration, spontaneous activity, $30 \mathrm{mM} \mathrm{KCl}$, and cumulative acetylcholine (Ach) contractility were recorded.

In order to measure cytokines, myeloperoxidase (MPO), glutathione (GSH), and malondialdehyde (MDA) activity, harvested blood and then tissues were immediately removed and cleaned with buffer solution and stored at $-80^{\circ} \mathrm{C}$ deep freeze.

\section{MDA Determination in the Intestinal Tissue}

MDA levels were detected using a method described by Casini et al. based on thiobarbituric acid reaction (15).

\section{Determine of GSH Levels in Intestinal Tissue}

The method described by Ellman was used to determine the level of GSH in intestinal tissue (16).

\section{Determinationt of MPO Activity in Ileum Homogenate}

The method described by Bradley et al. was used to determine the amount of myeloperoxidase (MPO), which is an indicator of migration of the neutrophils to the inflammed tissue (17).

\section{Determination of TNF- $\alpha$ and IL-1 $\beta$ Activities in Serum and Intestinal Tissue}

In both serum and tissue, the activity of TNF- $a$ and IL-1 $\beta$ was measured by following the instructions in the manufacturer's guideline papers (abcam ab100770, ab100768, respectively, Istanbul/Turkey).

\section{Statistical Analysis}

Statistical analysis was performed using a Kruskal-Wallis test, followed by a post hoc Bonferroni test to estimate the differences between groups. A two-way ANOVA with multiple post hoc 
comparisons performed with the Bonferroni test was used to determine the differences between the $150 \mathrm{~min}$ and $24 \mathrm{~h}$ series.

\section{RESULTS}

\section{Ileal Longitudinal Muscle Contractility}

As seen in Figure 1 with original traces, the cumulative dose of Ach (10-8-10-3 M) produced concentration-dependent contraction on isolated ileum in the sham, l/R-vehicle and TQ at $24 \mathrm{~h}$ after ischemia procedure. Contraction response of the cumulative dosing of Ach in the TQ group was almost as much as the response of the sham group at $24 \mathrm{~h}$ after ischemia while the cumulative effect of Ach in the 150-minute reperfusion group was not statistically significant. In 150 min reperfusion periods, statistical significance was not significant in the 150-minute reperfusion pediods as shown in Table 1 and Figure 2.

There were statistical differences between I/R-vehicle and sham groups in the Ach contraction responses both at 150 min (Figure 2A) and $24 \mathrm{~h}$ (Figure 2B) of the reperfusion periods. The inhibition of Ach-induced contraction due to I/R was reversed by TQ for the responses to 10-6 M-10-3 M Ach at $24 \mathrm{~h}(\mathrm{p}<0.05, \mathrm{p}<$ 0.0001), however, this effect of TQ was not observed at $150 \mathrm{~min}$ of reperfusion (Table 1). Therefore, biochemical analyses were only measured at $24 \mathrm{~h}$.

At $24 \mathrm{~h}$ of reperfusion, the depressed response of $\mathrm{KCl}$-induced contractions in the TQ treated I/R-vehicle group was reversed and a similarity was seen in the sham control group (Figure 3).
The ameliorating affects of $\mathrm{TQ}$ on the Ach and $\mathrm{KCl}$ contractile responses of the intestinal I/R tissue were observed only at 24 $\mathrm{h}$ of reperfusion even though there was no gain at $150 \mathrm{~min}$ of reperfusion (Table 1). Moreover, there was a statistical difference between the 150 min and $24 \mathrm{~h}$ reperfusion periods at $30 \mathrm{mM} \mathrm{KCl}$ when comparing TQ groups with each other.

\section{MDA Levels in the Intestinal Tissue at the $24 \mathrm{~h}$ of Reperfusion}

As shown in Figure 4A and Table 2, in the I/R-vehicle group, MDA level in the ileum homogenate was observed significantly higher than the Sham group at $24 \mathrm{~h}$ of reperfusion. Pre-treatment of a 50 $\mathrm{mg} / \mathrm{kg}$ dose of TQ significantly inhibited out the content of MDA.

\section{GSH Levels in the Intestinal Tissue at the $24 \mathrm{~h}$ of Reperfusion}

As illustrated in Figure 4B and Table 2, GSH levels in the intestinal homogenate of the I/R-vehicle animals were observed significantly lower than the sham group at $24 \mathrm{~h}$ of reperfusion. Pre-treatment with a $50 \mathrm{mg} / \mathrm{kg}$ dose of TQ, however, significantly improved the decreased quantity of GSH in theTQ pre-administered I/R-vehicle group, with a significantly higher GSH level.

\section{MPO Activity in the Intestinal Tissue at the $24 \mathrm{~h}$ of Reperfusion}

Figure 4C shows that the statistical significances were found between I/R-vehicle and sham groups and between TQ and I/R-vehicle groups at $24 \mathrm{~h}$ of reperfusion (Table 2 ).

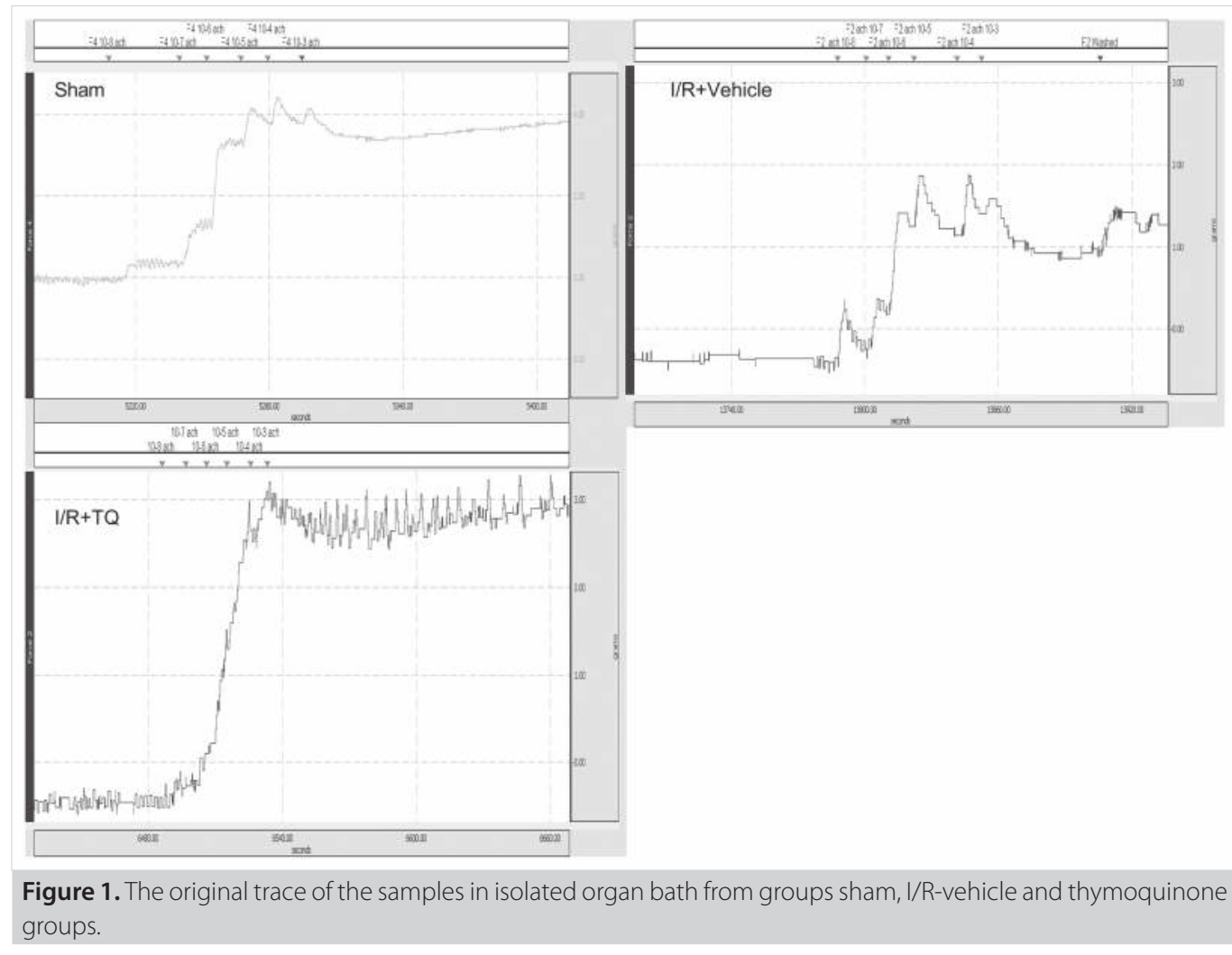


Table 1. Maximum contraction effects of Ach on the sham, $1 / R+$ vehicle and thymoquinone groups of an isolated rat ileum

\begin{tabular}{|c|c|c|c|c|c|c|}
\hline Ach Con. & $\begin{array}{l}\text { Reperfusion periods }(\mathrm{min} ; \mathrm{h}) \\
\qquad(\mathrm{n}=8)\end{array}$ & Sham & I/R+vehicle & Thymoquinone & p1 & p2 \\
\hline $10^{-8}$ & 150 & $24.23 \pm 5.61$ & $13.54 \pm 6.85$ & $18.46 \pm 7.44$ & $>0.999$ & $>0.999$ \\
\hline $10^{-8}$ & 24 & $24.33 \pm 5.13$ & $11.92 \pm 6.09$ & $18.46 \pm 7.44$ & 0.3632 & $>0.999$ \\
\hline $10^{-7}$ & 150 & $36.08 \pm 4.77$ & $16.46 \pm 5.19^{* *}$ & $23.15 \pm 5.91$ & 0.0067 & $>0.999$ \\
\hline $10^{-7}$ & 24 & $36.17 \pm 4.92$ & $14.96 \pm 4.31^{* *}$ & $26.15 \pm 5.91$ & 0.0002 & 0.8749 \\
\hline $10^{-6}$ & 150 & $64.34 \pm 3.98$ & $19.64 \pm 6.13^{* * *}$ & $30.27 \pm 8.41$ & $<0.0001$ & $>0.999$ \\
\hline $10^{-6}$ & 24 & $64.33 \pm 3.87$ & $21.28 \pm 6.46^{* * *}$ & $38.08 \pm 7.44^{\#}$ & $<0.0001$ & 0.0108 \\
\hline $10^{-5}$ & 150 & $85.00 \pm 5.40$ & $24.15 \pm 11.34^{* * *}$ & $38.46 \pm 10.05$ & $<0.0001$ & 0.3016 \\
\hline $10^{-5}$ & 24 & $85.33 \pm 4.89$ & $30.02 \pm 9.62^{* * *}$ & $54.67 \pm 10.50^{\# \# \#}$ & $<0.0001$ & $<0.0001$ \\
\hline $10^{-4}$ & 150 & $93.10 \pm 4.88$ & $28.26 \pm 8.01^{* * *}$ & $45.15 \pm 9.56$ & $<0.0001$ & 0.0506 \\
\hline $10^{-4}$ & 24 & $93.04 \pm 4.73$ & $37.58 \pm 7.56^{* * *}$ & $65.15 \pm 9.56^{\# \# \#}$ & $<0.0001$ & $<0.0001$ \\
\hline $10^{-3}$ & 150 & $95.12 \pm 4.89$ & $31.33 \pm 6.68^{* * *}$ & $48.08 \pm 11.34$ & $<0.0001$ & 0.0562 \\
\hline $10^{-3}$ & 24 & $95.11 \pm 4.82$ & $39.88 \pm 4.80^{* * *}$ & $68.08 \pm 11.41^{\# \# \#}$ & $<0.0001$ & $<0.0001$ \\
\hline $\mathrm{KCl}(30 \mathrm{mM})$ & 150 & $99.49 \pm 8.37$ & $42.43 \pm 17.46^{* * *}$ & $54.57 \pm 15.20^{\&}$ & 0.0003 & $>0.999$ \\
\hline $\mathrm{KCl}(30 \mathrm{mM})$ & 24 & $99.63 \pm 10.34$ & $50.70 \pm 16.60^{* *}$ & $86.24 \pm 15.55^{\#}$ & 0.0011 & 0.0126 \\
\hline
\end{tabular}

Data are expressed as mean $\pm S D(n=8)$. p1: $p$ value between I/R and Sham control groups, $p 2: p$ value between TQ and I/R groups. \#\#: $p<0.01, * * *$,\#\#; $p<0.001$, \& Sign between $150 \mathrm{~min}$ and $24 \mathrm{~h}$ reperfusion, $\mathrm{p}<0.05$.

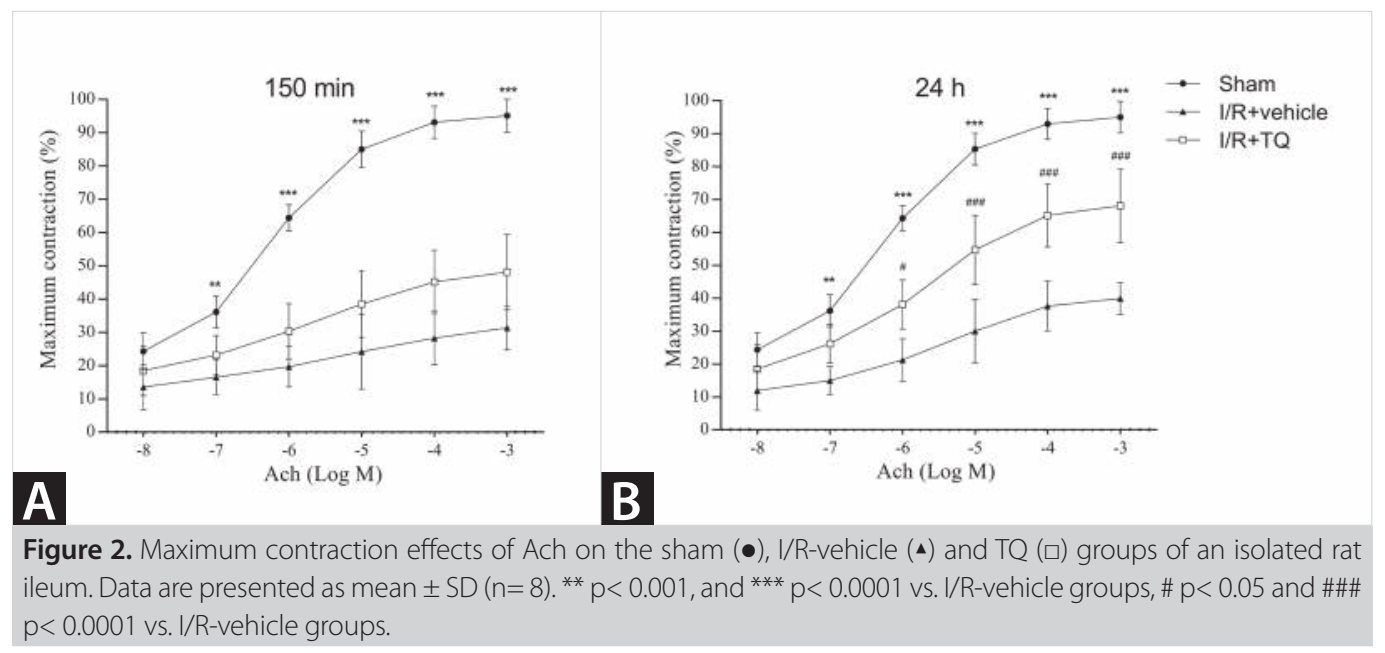

Level of TNF- $a$ in Serum and Intestinal Tissue at the $24 \mathrm{~h}$ of Reperfusion

As shown in Figure $5 \mathrm{~A}$ and $5 \mathrm{~B}$, in the I/R-vehicle group, the TNF-a levels in serum and ileum homogenate were observed significantly higher than the Sham group at $24 \mathrm{~h}$ of reperfusion. Pre-treatment of a $50 \mathrm{mg} / \mathrm{kg}$ dose of TQ significantly inhibited out the levels of TNF-a in the serum and tissue homogenate.

\section{IL-1 $\beta$ Assay in Serum and Intestinal Tissue at the $24 \mathrm{~h}$ of Reperfusion}

The other criteria of the size of the I/R-induced ileum injury is the determination of IL-1 $\beta$ levels in the serum and ileum tissue. As illustrated in Table 2, when the I/R-vehicle groups and sham groups were compared in terms of IL-1 $\beta$ levels in both the serum and ileum homogenate, the increase in all of these parameters in the I/R-vehicle groups was statistically different. There was a statistically significant difference when compared to a 50 $\mathrm{mg} / \mathrm{kg}$ dose of TQ group with I/R-vehicle group in the serum (Figure 5C) and tissue homogenate (Figure 5D).

\section{DISCUSSION}

The results of the present research revealed that intestinal I/R resulted in a depressed ileum contractile responses to $\mathrm{KCl}$, unspecific K ion channels related to contractility, and Ach, an excitatory neurotransmitter that effects by cholinergic induction in the smooth muscle cells of the digestive system. TQ administra- 


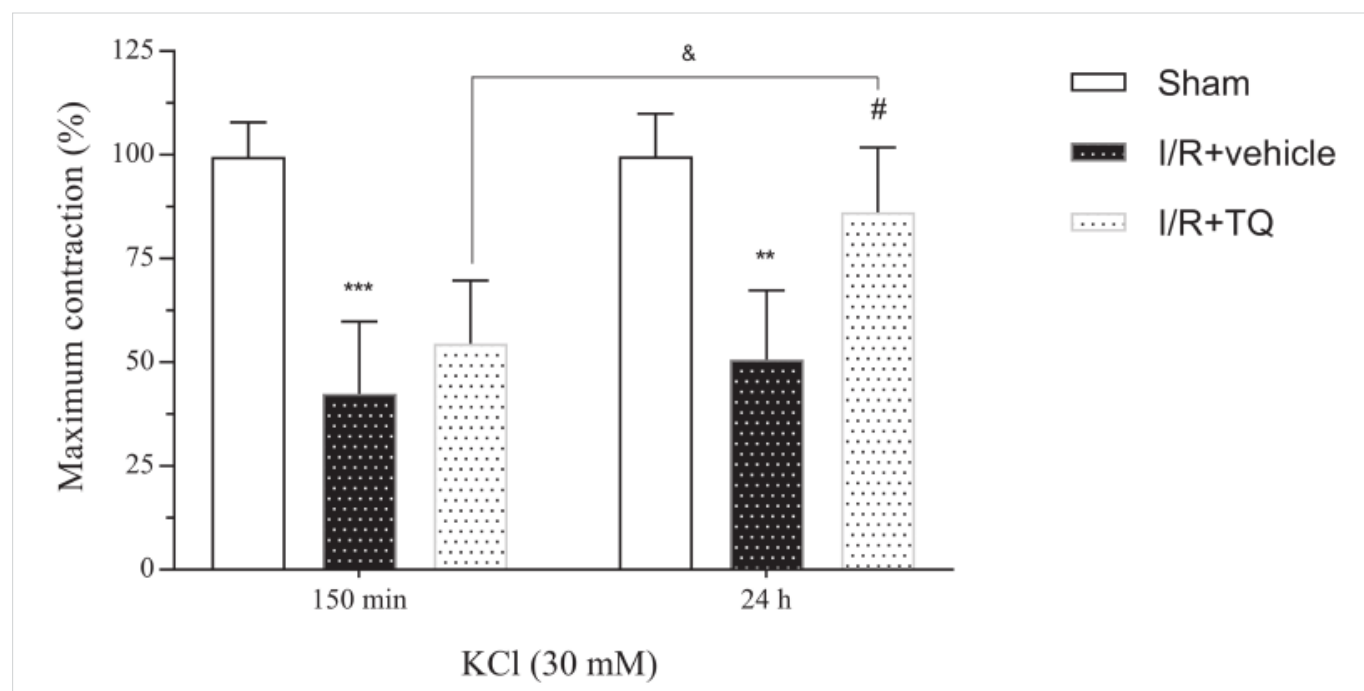

Figure 3. The response of resveratrol to $30 \mathrm{mM} \mathrm{KCl}$ in intestinal muscle in the $\mathrm{l} / \mathrm{R}$ model. TQ was tested at $50 \mathrm{mg} / \mathrm{kg}$ dose once a day throughout 3 days before surgery. Data are expressed as mean \pm SD. Statistically significant differences were found when comparing the $I / R+$ vehicle with the sham group $\left({ }^{* * *} p<0.0001,150\right.$ min; ${ }^{* *} p<0.001,24 \mathrm{~h}$ reperfusion; $n=8$ ). Statistically significant differences were only found at $24 \mathrm{~h}$ of reperfusion when comparing the TQ group with the $\mathrm{I} / \mathrm{R}+$ vehicle groups ( $p<0.05 ; n=8 ; 24 \mathrm{~h}$ reperfusion). There was a statistical difference between the 150 min and $24 \mathrm{~h}$ reperfusion periods at $30 \mathrm{mM} \mathrm{KCl}$ when comparing TQ groups with each other $(\& \mathrm{p}<0.05)$.

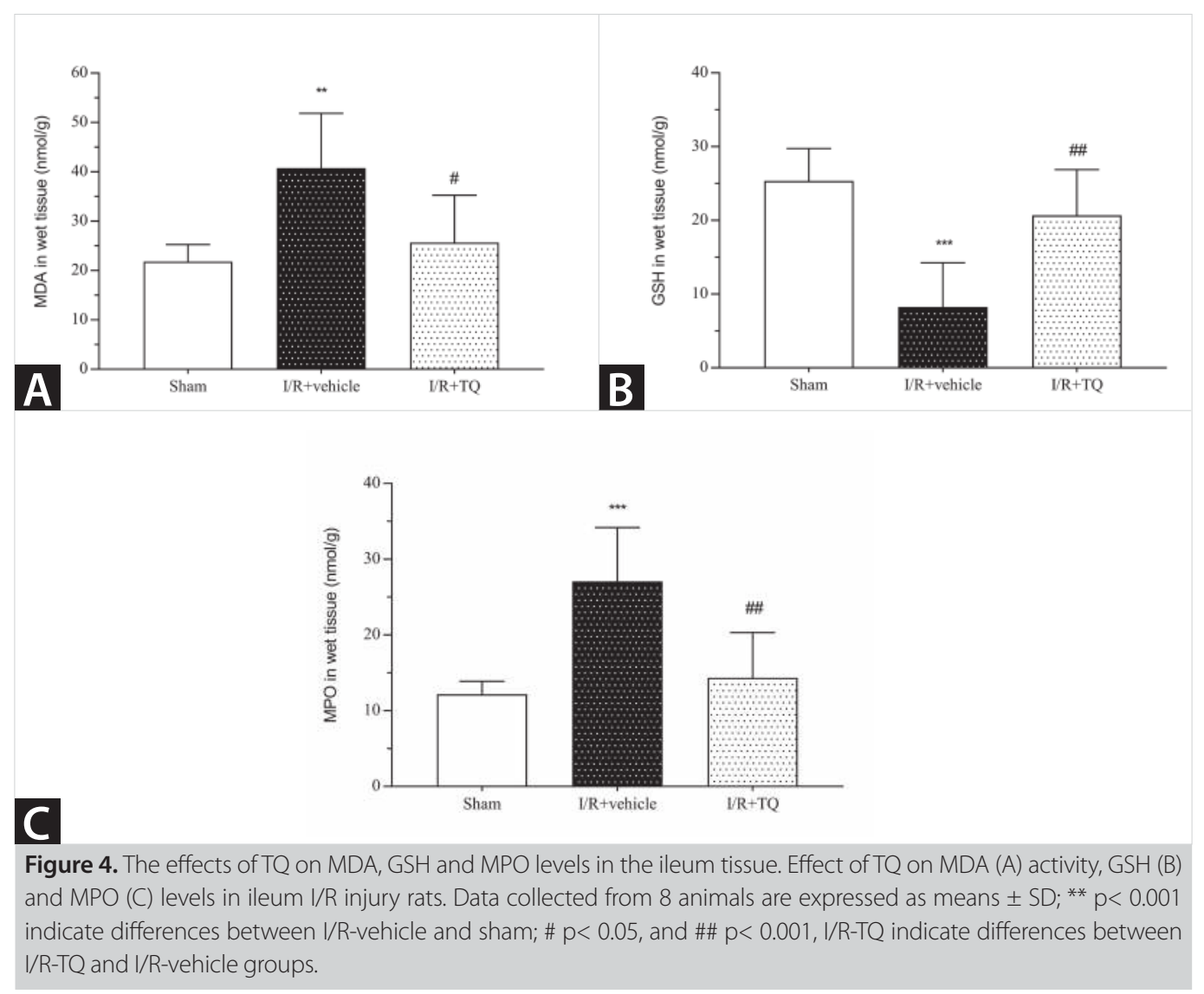


Table 2. Comparison of oxidative stress and cytokine levels between the groups

\begin{tabular}{|c|c|c|c|c|c|c|}
\hline Ach Con. & $\begin{array}{l}\text { Reperfusion periods (min; } h) \\
\qquad(n=8)\end{array}$ & Sham & I/R+vehicle & $\mathrm{I} / \mathrm{R}+\mathrm{TQ}$ & p1 & p2 \\
\hline MDA (nmol/g) in tissue & 24 & $21.83 \pm 3.43$ & $40.75 \pm 11.13^{* *}$ & $25.67 \pm 9.63^{\#}$ & 0.0057 & 0.0272 \\
\hline GSH (nmol/mg) in tissue & 24 & $25.33 \pm 4.41$ & $8.25 \pm 6.01^{* * *}$ & $20.67 \pm 6.22^{\# \#}$ & 0.0003 & 0.0048 \\
\hline MPO $(\mathrm{nmol} / \mathrm{mg})$ in tissue & 24 & $12.17 \pm 1.72$ & $27.08 \pm 7.09^{* * *}$ & $14.33 \pm 5.98^{\# \#}$ & 0.0008 & 0.0031 \\
\hline TNF-a $(\mathrm{pg} / \mathrm{mL})$ in serum & 24 & $749.67 \pm 97.45$ & $2955.12 \pm 880.22^{* * *}$ & $1650.41 \pm 417.37^{\# \#}$ & $<0.0001$ & 0.0056 \\
\hline TNF-a (pg/g) in tissue & 24 & $52.70 \pm 5.50$ & $107.50 \pm 23.47^{* * *}$ & $64.40 \pm 20.38^{\# \#}$ & 0.0003 & 0.0029 \\
\hline IL-1 $\beta(p g / m L)$ in serum & 24 & $258.83 \pm 42.37$ & $1127.33 \pm 230.34^{* * *}$ & $597.17 \pm 75.03^{\# \#}$ & $<0.0001$ & 0.0027 \\
\hline IL-1 $\beta(p g / g)$ in tissue & 24 & $6.78 \pm 0.24$ & $15.86 \pm 3.63^{* * *}$ & $7.48 \pm 2.50^{\# \# \#}$ & $<0.0001$ & 0.0001 \\
\hline
\end{tabular}

Data are expressed as mean $\pm S D(n=8) . p 1: p$ value between I/R-vehicle and sham groups, ${ }^{* *} p<0.001,{ }^{* * *} p<0.0001$. $p 2: p$ value between I/R-TQ and I/R-vehicle groups, \# $p<0.05 \# \# p<0.01$, \#\#\# $p<0.001$.

Data are presented as mean \pm Standard Deviation (SD; $n=8$ ). ${ }^{* *} p<0.001$, and ${ }^{* * *} p<0.0001$ vs. sham groups; \# $p<0.05$, \#\# $p<0.001$, and \#\#\# $p<0.0001$ vs. I/R-vehicle groups.
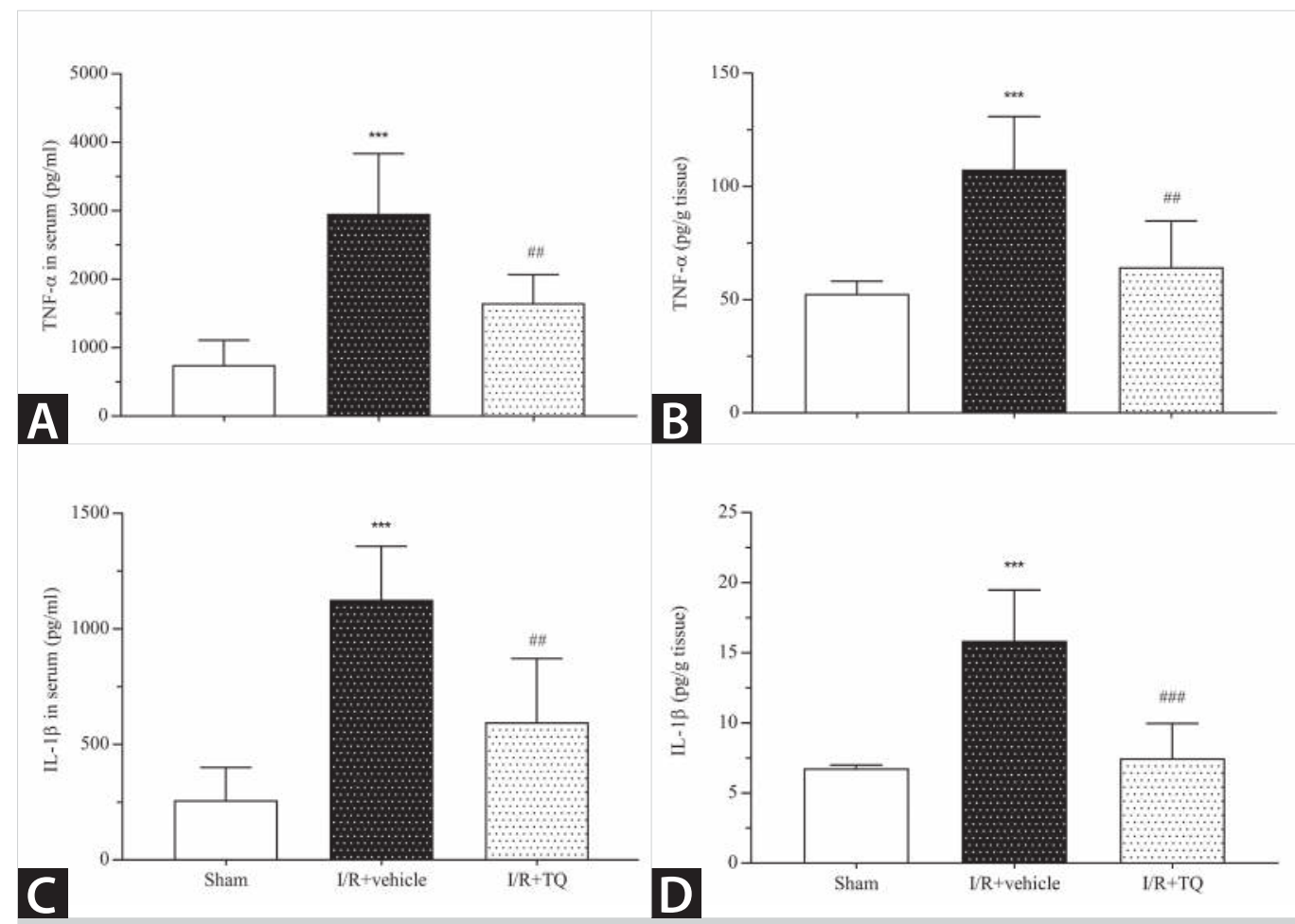

Figure 5. The effects of TQ on TNF- $a$ and IL-1 $\beta$ in serum and ileum tissue. Effect of TQ on TNF-a level in serum (A) and ileum tissue (B), IL-1 $\beta$ activity in serum (C) and tissue (D). Data collected from 8 animals are expressed as means \pm SD ( $\mathrm{pg} / \mathrm{mL}$ in serum; $\mathrm{pg} / \mathrm{g}$ in wet tissue); ${ }^{* *} \mathrm{p}<0.0001$ indicate differences between I/R-vehicle and sham; \#\# $\mathrm{p}<0.001$ and \#\#\# $\mathrm{p}<0.0001$ indicate differences between I/R-TQ and I/R-vehicle groups.

tion was noticed ameliorate the distrupted contractile responses at $24 \mathrm{~h}$ after $\mathrm{I} / \mathrm{R}$, whereas it seemed to have no improvement at $150 \mathrm{~min}$ of $\mathrm{I} / \mathrm{R}$.

The ileum contraction response due to I/R damage of intestinal tissue is significantly impaired (3). Inflammatory mediators, ROS, leukocyte migration, and events in the immune processes can trigger the contractile chaos of the smooth muscle induced by
I/R. It is known that I/R causes endothelium integrity, endothelial dysfunction, and failure in the oxydant defence mechanisms $(2,3,5)$. In order to understand the therapeutic effect of TQ in intestinal I/R injury well, markers of oxidative stress and inflammation such as MDA, GSH, MPO and TNF-a activities in the ileum tissue were investigated. The results indicated that stimulated cytokine, neutrophilic inflammation and oxidative events play a role in I/R-induced intestinal damage. Fortunately, pretreatment 
of animals with TQ restored intestinal dysfunction, reduced elevated MDA, MPO, TNF-a levels and reversed the depleted intestine GSH levels at I/R 24.

One of the unpredictive result was that we did not observe the reverse effect of distrupted contractily at the 150th min of reperfusion, while it was significantly decreased at the $24 \mathrm{~h}$ of reperfusion by TQ administration. Actually, a dose of $50 \mathrm{mg} /$ $\mathrm{kg} / \mathrm{bw}$ of TQ was chosen according to a previous paper $(13,14)$. That dose may be insufficient to carry out a therapy for acute I/R injury. Another limitation about our research protocol may be the oral route of application of TQ to animals. In several investigations, unlike us, the application of antioxidant agent has been intravenous infusion just before ischemia (5). On the other hand, active TQ in the body can affect the liver due to its inactive biotransformation tract (18). Therefore, future studies are needed to plan the application routes of TQ in pathogenesis of I/R injury in detail.

The results of the present study on smooth muscle functions revealed that intestinal I/R injury was appreciably reduced by TQ preapplication. According to the literature, oxidant stress is a basic mechanism on inflammation and pathogenesis in intestinal I/R injury (13). This study revealed that increased MDA levels reversed with three times TQ administration prior to I/R surgery operation. In addition, GSH has non-enzymatic antioxidant structures of cells to protect against to oxidant processes $(13,19)$. TQ elevated the deppressed GSH level of intestinal cells. These results indicate that TQ has attributed to the upregulation of endogenous cellular antioxidant systems during the progress of subacute I/R injury. MPO activity is often discussed to show the extent of inflammation in intestinal tissues subjected to I/R injury. Our study revealed that the increased MPO activity inhibited with three times TQ administration prior to I/R surgery operation.

Recent studies have revealed that the suppression of overproduction of pro-inflammatory cytokines including TNF-a and IL$1 \beta$ occurs in exaggerated immunity or inflammation of disease models such as asthma, rheumatic arthritis, cancers, neurodegenerative diseases, cardiotoxicity, and etc. by TQ (12,20-24). Our results showed that TQ administration inhibits both ileum tissue and plasma TNF- $a$ and IL-1 $\beta$ expressions in intestinal I/R injury. Cytokine production ring can occur due to the migration of polymorphonuclear leukocytes to the injured tissue.

Some limitations of this study are about other probable effect mechanisms of TQ on I/R injured tissue pathogenesis. One mechanism of TQ may be that it enhances the expression of endothelial nitric oxide synthase and increases nitric oxide levels, potent antioxidant which reacts with toxic molecular radicals, along with down-regulated nitric oxide synthase expression (25). TQ may have improved effects on endoplasmic stress and mitochondrial dysfunction and anti-apoptotic effects through activation of autophagy in damaged cells following numerous I/R models (13,26-29).

\section{CONCLUSION}

Our results confirm that TQ has antioxidant and aniinflammatory activities in the prevention and therapy of intestinal I/R injury. However, for clinical use, the dose, effect, and safety of TQ must be investigated by clinical phase studies in healthy volunteers or patients with numerous diseases. Finally, the results of the current study clearly reveal the role of oxidative damage in the immuno-pathophysiology of intestinal I/R injury, and in fact, TQ can be useful as a prophylactic and therapeutic agent in intestinal I/R injury.

Ethics Committee Approval: The approval of the animal ethical committee of Duzce University was taken with the number: 2011/009.

Peer-review: Externally peer-reviewed.

Author Contributions: Concept - S.O.A.; Design - S.O.A., A.P.; Supervision - S.O.A.; Resource - A.P.; Materials - A.P.; Data Collection and/or Processing S.O.A., A.P.; Analysis and/or Interpretation - A.P.; Literature Search - S.O.A.; Writing Manuscript - S.O.A.; Critical Reviews - S.O.A., A.P.

Conflict of Interest: The authors declare that they have no conflict of interests.

Financial Disclosure: The authors declared that this study has received no financial support.

\section{REFERENCES}

1. Carden DL, Granger DN. Pathophysiology of ischaemia-reperfusion injury. J Pathol 2000;190:255-66. [CrossRef]

2. Ozacmak VH, Sayan H, Arslan SO, Altaner S, Aktas RG. Protective effect of melatonin on contractile activity and oxidative injury induced by ischemia and reperfusion of rat ileum. Life Sci 2005;76:1575-88. [CrossRef]

3. Arslan SO, Gelir E, Sayan H, Haktan Ozacmak V. L-arginine and melatonin interaction in rat intestinal ischemia-reperfusion. Fundam Clin Pharmacol 2005; 19:533-5. [CrossRef]

4. Hierholzer C, Kalff JC, Audolfsson G, Billiar TR, Tweardy DJ, Bauer AJ. Molecular and functional contractile sequelae of rat intestinal ischemia/reperfusion injury. Transplantation 1999;68:1244-54. [CrossRef]

5. Sayan H, Ozacmak VH, Altaner S, Aktas RG, Arslan SO. Protective effects of L-arginine on rat terminal ileum subjected to ischemia/reperfusion. J Pediatr Gastroenterol Nutr 2008;46:29-35. [CrossRef]

6. Ragheb A, Attia A, Eldin WS, Elbarbry F, Gazarin S, Shoker A. The protective effect of thymoquinone, an anti-oxidant and anti-inflammatory agent, against renal injury: a review. Saudi J Kidney Dis Transpl 2009;20:741-52. [CrossRef]

7. Mutabagani A, Journal SE-M-, 1997 undefined. A study of the antiinflammatory activity of Nigella sativa L. and thymoquinone in rats. SAUDI Pharm. [CrossRef]

8. Houghton P, Zarka R, de las Heras B, Hoult J. Fixed Oil of Nigella sativa and Derived Thymoquinone Inhibit Eicosanoid Generation in Leukocytes and Membrane Lipid Peroxidation. Planta Med 1995;61:33-6. [CrossRef] 
9. Woo C, Kumar A, Sethi G, pharmacology KT-B, 2012 undefined. Thymoquinone: potential cure for inflammatory disorders and cancer. Elsevier. [CrossRef]

10. Salem ML. Immunomodulatory and therapeutic properties of the Nigella sativa L. seed. Int Immunopharmacol 2005;5:1749-70. [CrossRef]

11. Arslan SO, Gelir E, Armutcu F, Coskun O, Gurel A, Sayan H, et al. The protective effect of thymoquinone on ethanol-induced acute gastric damage in the rat. Nutr Res 2005;25:673-80. [CrossRef]

12. Ammar ESM, Gameil NM, Shawky NM, Nader MA. Comparative evaluation of anti-inflammatory properties of thymoquinone and curcumin using an asthmatic murine model. Int Immunopharmacol 2011;11:2232-6. [CrossRef]

13. Tas U, Ayan M, Sogut E, Kuloglu T, Uysal M, Tanriverdi HI, et al. Protective effects of thymoquinone and melatonin on intestinal ischemiareperfusion injury. Saudi J Gastroenterol 2015;21:284-9. [CrossRef]

14. El-Abhar H, Abdallah D, Saleh S. Gastroprotective activity of Nigella sativa oil and its constituent, thymoquinone, against gastric mucosal injury induced by ischaemia/reperfusion in rats. J Ethnopharmacol 2003:84:251-8. [CrossRef]

15. Casini AF, Ferrali M, Pompella A, Maellaro E, Comporti M. Lipid peroxidation and cellular damage in extrahepatic tissues of bromobenzene-intoxicated mice. Am J Pathol 1986;123:520-31. [CrossRef]

16. SedlakJ, Lindsay RH. Estimation of total, protein-bound, and nonprotein sulfhydryl groups in tissue with Ellman's reagent. Anal Biochem 1968;25:192-205. [CrossRef]

17. Bradley PP, Priebat DA, Christensen RD, Rothstein G. Measurement of cutaneous inflammation: estimation of neutrophil content with an enzyme marker. J Invest Dermatol 1982;78:206-9. [CrossRef]

18. Abd-Elbaset M, Arafa E-SA, El Sherbiny GA, Abdel-Bakky MS, Elgendy ANAM. Thymoquinone mitigate ischemia-reperfusion-induced liver injury in rats: a pivotal role of nitric oxide signaling pathway. Naunyn Schmiedebergs Arch Pharmacol 2017;390:69-76. [CrossRef]

19. Arslan SO, Zerin M, Vural H, Coskun A. The effect of melatonin on bleomycin-induced pulmonary fibrosis in rats. J Pineal Res 2002;32:21-5. [CrossRef]

20. Vaillancourt F, Silva P, Shi Q, Fahmi H, Fernandes JC, Benderdour M. Elucidation of molecular mechanisms underlying the protective effects of thymoquinone against rheumatoid arthritis. J Cell Biochem 2011;112:107-17. [CrossRef]
21. Darakhshan S, Bidmeshki Pour A, Hosseinzadeh Colagar A, Sisakhtnezhad S. Thymoquinone and its therapeutic potentials. Pharmacol Res 2015;95-96:138-58. [CrossRef]

22. Çelik F, Göçmez C, Karaman H, Kamaşak K, Kaplan I, Akıl E, et al. Therapeutic effects of thymoquinone in a model of neuropathic pain. Curr Ther Res 2014;76:11-6. [CrossRef]

23. Nagi MN, Al-Shabanah OA, Hafez MM, Sayed-Ahmed MM. Thymoquinone supplementation attenuates cyclophosphamide-induced cardiotoxicity in rats. J Biochem Mol Toxicol 2011;25:135-42. [CrossRef]

24. Robinson ES, Alves P, Bashir MM, Zeidi M, Feng R, Werth VP. Cannabinoid reduces inflammatory cytokines tumor necrosis factor alpha and type I interferons in dermatomyositis in vitro. J Invest Dermatol 2017. [CrossRef]

25. Abd-Elbaset M, Arafa E-SA, El Sherbiny GA, Abdel-Bakky MS, Elgendy ANAM. Thymoquinone mitigate ischemia-reperfusion-induced liver injury in rats: a pivotal role of nitric oxide signaling pathway. Naunyn Schmiedebergs Arch Pharmacol 2017;390:69-76. [CrossRef]

26. Bouhlel A, Ben Mosbah I, Hadj Abdallah N, Ribault C, Viel R, Mannai $S$, et al. Thymoquinone prevents endoplasmic reticulum stress and mitochondria-induced apoptosis in a rat model of partial hepatic warm ischemia reperfusion. Biomed Pharmacother 2017;94:964-73. [CrossRef]

27. Bouhlel A, Bejaoui M, Ben Mosbah I, Hadj Abdallah N, Ribault C, Viel R, et al. Thymoquinone protects rat liver after partial hepatectomy under ischaemia/reperfusion through oxidative stress and endoplasmic reticulum stress prevention. Clin Exp Pharmacol Physiol 2018;45:94351. [CrossRef]

28. Xiao J, Ke Z-P, Shi Y, Zeng Q, Cao Z. The cardioprotective effect of thymoquinone on ischemia-reperfusion injury in isolated rat heart via regulation of apoptosis and autophagy. I Cell Biochem 2018;119:7212-7. [CrossRef]

29. Lu Y, Feng Y, Liu D, Zhang Z, Gao K, Zhang W, et al. Thymoquinone Attenuates Myocardial Ischemia/Reperfusion Injury Through Activation of SIRT1 Signaling. Cell Physiol Biochem 2018:47:1193-206. [CrossRef] 


\title{
ORIJINAL ÇALIŞMA-ÖZET
}

Turk J Surg 2020; 36 (1): 96-104

\section{Timokinon, bir antioksidan ve antienflamatuvar etki ile bağlantılı olarak sıçanlarda iskemi ve reperfüzyonun neden olduğu bağırsak hasarını azaltır}

\author{
Ali Parlar ${ }^{1}$, Seyfullah Oktay Arslan² \\ ${ }^{1}$ Adıyaman Üniversitesi Tıp Fakültesi, Tıbbi Farmakoloji Anabilim Dalı, Adıyaman, Türkiye \\ ${ }^{2}$ Ankara Yıldırım Beyazıt Üniversitesi Tıp Fakültesi, Tıbbi Farmakoloji Anabilim Dalı, Ankara, Türkiye
}

\section{ÖZET}

Giriş ve Amaç: Bu çalışmanın amacı, erkek wistar sıçanlarında timokinonun iskemi/reperfüzyon (I/R) yaralanmasına 150 dakika veya 24 saat reperfüzyon üzerindeki etkisini araştırmaktır.

Gereç ve Yöntem: Timokinonun reaktif oksijen türlerinin veya bağırsak iskemisi/reperfüzyonunda inflamatuvar süreçlerin neden olduğu hücresel hasar üzerindeki terapötik değeri, asetilkolinin (Ach) ve KCl'nin düzgün kas kasılma yanıtları, malondialdehit ile birlikte düz kas kasılma yanıtları üzerinde farmakolojik fonksiyon çalışmaları kullanılarak incelendi. Sıçanların serumları ve ileum dokularında tümör nekroz faktörü (TNF)-a ve interlökin (IL)-1 $\beta$ gibi glutatyon ve sitokin seviyeleri de incelendi. Timokinon $50 \mathrm{mg} / \mathrm{kg}$ dozda cerrahi işlemden 30 dakika önce, işlem sonrası 24 . saatte ve işlem sonrası 48. saatte olmak üzere oral yoldan üç kez uygulandı. Reperfüzyon zamanlamasından kısa bir süre sonra (150. dakika veya 24. saat), KCl'ye bağlı kontraktilite izleri ve ileum düz kas asetilkolin izole organ banyosuna kaydedildi.

Bulgular: Timokinon ile ön tedavi, 24 saat reperfüzyonda ileum düz kasının bozulmuş kasılma kontraktilitesini tersine çevirmiştir. Artan malondialdehit ve tükenmiş glutatyon seviyeleri ve ileum I/R dokusunda belirlenen yüksek miyeloperoksidaz aktivitesi, malondialdehit miktarını azaltan, glutatyon seviyesini eski haline getiren ve miyeloperoksidaz aktivitesini önleyen timokinon ön tedavisi ile makul miktarlara getirilmiştir. Ek olarak, hem serum hem de doku TNF-a ve IL-1 $\beta$ aktiviteleri 24 saatlik intestinal I/R'de timokinon ile modüle edilmiştir.

Sonuç: Timokinonun, oksidan hasar mekanizmaları içeren bağırsak I/R yaralanmasında immünomodüle edici, radikal temizleyici ve/veya antioksidan etkileriyle terapötik değere sahip olabileceğini gösterir.

Anahtar Kelimeler: Timokinon, bağırsak iskemi ve reperfüzyon, ileum düz kas kasılması, sitokinler, oksidatif yaralanma

Doi: $10.5578 /$ turkjsurg.4583 